\title{
Synthesis and Characterization of CZTS Thin Films by Sol-Gel Method without Sulfurization
}

\author{
Xiaoqi Yu, Aobo Ren, Fogen Wang, Ci Wang, Jingquan Zhang, Wenwu Wang, \\ Lili Wu, Wei Li, Guanggen Zeng, and Lianghuan Feng
}

College of Materials Science and Engineering, Sichuan University, Chengdu 610064, China

Correspondence should be addressed to Jingquan Zhang; zjq100@hotmail.com and Wenwu Wang; 93319189@qq.com

Received 10 February 2014; Revised 28 May 2014; Accepted 28 May 2014; Published 22 July 2014

Academic Editor: Sudhakar Shet

Copyright (C) 2014 Xiaoqi Yu et al. This is an open access article distributed under the Creative Commons Attribution License, which permits unrestricted use, distribution, and reproduction in any medium, provided the original work is properly cited.

One process of layer-by-layer sol-gel deposition without sulfurization was developed. The CZTS films with $1.2 \mu \mathrm{m}$ and the sulfur ratio of $\sim 48 \%$ were prepared and their characteristics were measured. The as-deposited and annealed films are of Kesterite structure. The as-deposited films do not present obvious electric conduction type. However, the annealed 9-LAY-ANN film is p-type conduction and has sheet resistance of $4.08 \mathrm{k} \Omega / \square$ and resistivity of $4.896 \times 10^{-1} \Omega \cdot \mathrm{cm}$. The optic energy gap is $1.50 \mathrm{eV}$ for as-deposited films and is $1.46 \mathrm{eV}$ after being annealed. The region deposited by using Lo-Con solution is more compact than that by the Hi-Con solution from SEM morphology images.

\section{Introduction}

Great attention is paid to the earth-abundant and nontoxic CZTS $\left(\mathrm{Cu}_{2} \mathrm{ZnSnS}_{4}\right)$ as a potential candidate for a light absorbing layer in thin film solar cell devices. The theoretical conversion efficiency of single-junction CZTS solar cell is $32.2 \%$ [1], because of its high absorption coefficient over $10^{4} \mathrm{~cm}^{-1}$ and a suitable direct band gap of $1.4-1.5 \mathrm{eV}$. In general, the methods of fabricating CZTS films consist of the vacuum-based and the liquid-based techniques. The deposition systems are so expensive that they possibly increase the manufacturing cost for the vacuum-based technology, such as thermal evaporation [2] and Magnetron sputtering [3, 4]. However, the low-cost manufacturing system and process can be adopted by liquid-based technology, such as screen printing $[5,6]$, chemical bath deposition [7], electro-deposition [8], and sol-gel method [9-15].

The optical and electronic properties of CZTS films are dependent on their composition. So the sulfurization process is an indispensable step for vacuum-based techniques in order to obtain the stoichiometric film, because sulfur is apt to be deficient in the vacuum ambiance owing to its high saturation vapor pressure. On the other hand, the toxic $\mathrm{H}_{2} \mathrm{~S}$ was often used for the liquid-based deposition techniques to avoid S-deficiency during the annealing process [5, 9-13]. So the liquid-based techniques without intentional sulfurization were developed by some research groups $[6-8,14,15]$. Park et al. reported the CZTS film of $563 \mathrm{~nm}$ thickness with the ratio of S being about $50 \%$, which was prepared by using solgel technology, by adding excess thiourea into the solution [15]. Yeh et al. reported the CZTS film of $2.9 \mu \mathrm{m}$ with the ratio of $S$ below $40 \%$, which was prepared by layer-by-layer sol-gel technology in air with the synthetizing temperature of $593 \mathrm{~K}$ [14].

Usually, the thickness of CZTS thin film used as solar cell absorbing layer should be more than $1 \mu \mathrm{m}$ with the purpose of absorbing the light sufficiently and the ratio of sulfur should be about $50 \%$, in order to ensure optical and electronic properties of the film.

In this work, one process of layer-by-layer sol-gel (LBLSG) deposition without sulfurization was developed. The CZTS films with $1.2 \mu \mathrm{m}$ and the sulfur ratio of $\sim 48 \%$ were prepared and their characteristics were measured.

\section{Experiment}

The sol-gel solutions for CZTS precursors were prepared by dissolving $\mathrm{CuCl}_{2} \cdot 2 \mathrm{H}_{2} \mathrm{O}, \mathrm{Zn}\left(\mathrm{CH}_{3} \mathrm{COO}_{2}\right)_{2} \cdot 2 \mathrm{H}_{2} \mathrm{O}, \mathrm{SnCl}_{2} \cdot 2 \mathrm{H}_{2} \mathrm{O}$, and $\mathrm{CH}_{4} \mathrm{~N}_{2} \mathrm{~S}$ into 2-methoxyethanol (2-metho) and 
TABLE 1: The amount of starting materials in the two solutions.

\begin{tabular}{lcccccc}
\hline Solution & $\mathrm{CuCl}_{2} \cdot 2 \mathrm{H}_{2} \mathrm{O}(\mathrm{mmol})$ & $\mathrm{Zn}(\mathrm{ac})_{2} \cdot 2 \mathrm{H}_{2} \mathrm{O}(\mathrm{mmol})$ & $\mathrm{SnCl}_{2} \cdot 2 \mathrm{H}_{2} \mathrm{O}(\mathrm{mmol})$ & $\mathrm{CH}_{4} \mathrm{~N}_{2} \mathrm{~S}(\mathrm{mmol})$ & $2-\mathrm{metho}(\mathrm{mL})$ & $\mathrm{MEA}(\mathrm{mL})$ \\
\hline Hi-Con & 14.4 & 9.6 & 8 & 64 & 10 & 1 \\
Lo-Con & 3.6 & 2.4 & 2 & 16 & 10 & 1 \\
\hline
\end{tabular}

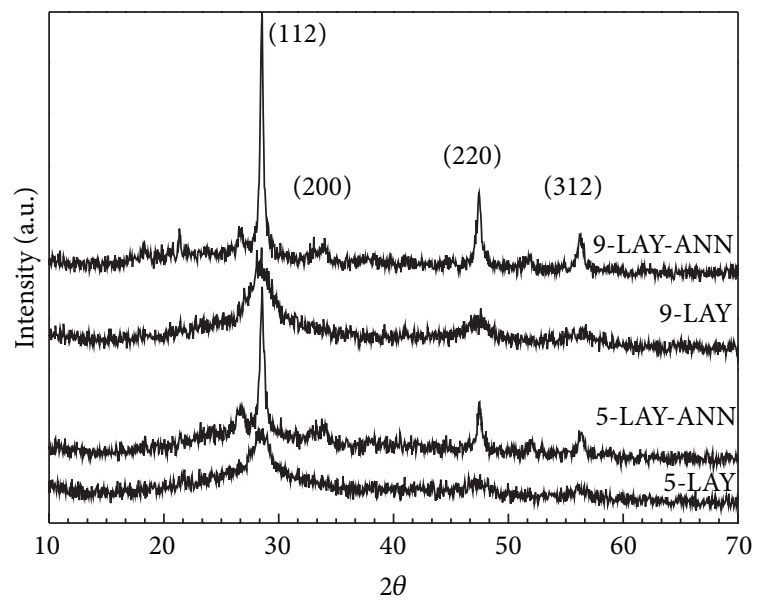

(a)

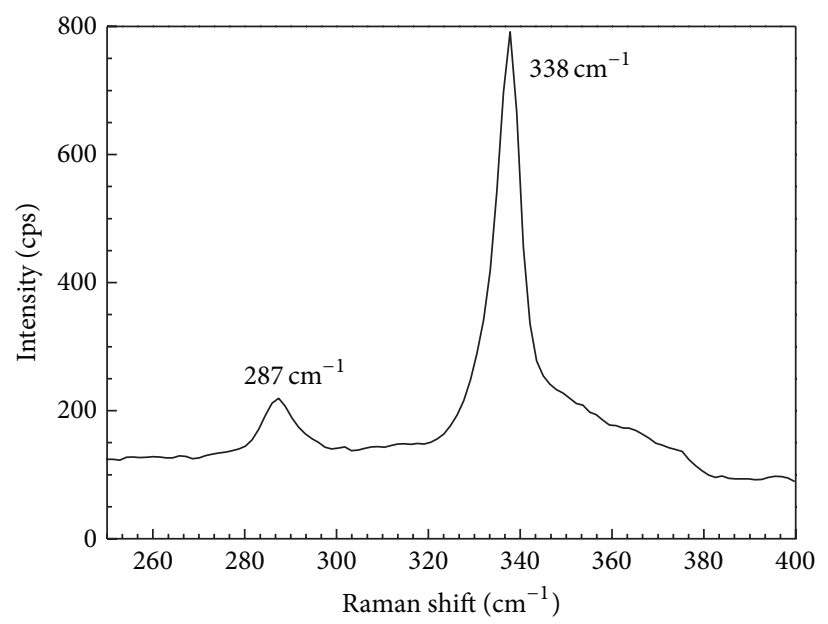

(b)

FIGURE 1: (a) XRD patterns of the CZTS films. (b) Raman spectrum of 9-LAY-ANN CZTS thin film.

monoethanolamine (MEA). The 2-metho and MEA were used as the solvent and the stabilizer, respectively. Two types of sol-gel solutions, named as Hi-Con and Lo-Con, were prepared by the recipe shown in Table 1 . Each solution was stirred for $20 \mathrm{~min}$ at $300 \mathrm{~K}$. The vicious yellow solution $\mathrm{Hi}$-Con was used to make the film thick enough and the pale yellow solution Lo-Con aimed to make the film surface smooth and compact.

CZTS films were deposited on the borosilicate glass. The procedures to deposit each layer in the LBLSG included spincoating, drying, and baking. Firstly the solution was dropped and rotated for $60 \mathrm{~s}$ at $3000 \mathrm{rpm}$; secondly the spin-coated films were dried at $393 \mathrm{~K}$ for $2 \mathrm{~h}$ in air on the hot plate; thirdly the dried samples were baked at $523 \mathrm{~K}$ for $10 \mathrm{~min}$ under nitrogen atmosphere in the quartz tube to prevent $\mathrm{O}_{2}$ affecting the film. Three samples were prepared. The sample 3-LAY was deposited up to three layers on the borosilicate glass, using solution Lo-Con by LBLSG process. The sample 5-LAY was deposited up to 5 layers, which was deposited with two layers by using solution Hi-Con on the sample 3LAY. The sample 9-LAY was deposited up to 9 layers, which was deposited with four layers by using solution Lo-Con on the sample 5-LAY. The as-deposited samples of 5-LAY and 9LAY were annealed at $773 \mathrm{~K}$ for 60 min under $\mathrm{N}_{2}$ atmosphere, named as 5-LAY-ANN and 9-LAY-ANN, respectively.

The structure and phase were characterized by $\mathrm{X}$-ray diffraction (XRD) by using a DX-2500 XRD diffractometer from Dandong Fangyuan Instrument LLC, China. The Raman spectrum was recorded by using a LabRAM-HR Raman Spectrometer from Horiba-Jobin Yvon Ibh Ltd. The film morphologies of surface and cross section were observed by a Hitachi S-4800 scanning electron microscope (SEM), and the compositions were determined by energy dispersive spectrometer (EDS) attached to SEM. X-ray photoelectron spectroscopy (XPS) was measured in order to analyze the element chemical valence state of films via an X-ray photoelectron spectroscope (KRATOS, AXIS Ultra DLD). The transmittance was measured using a UV-VIS-NIR spectrophotometer PerkinElmer Lambda 950 with $150 \mathrm{~mm}$ integrating sphere. The film thickness was determined by a surface profiler (XP-2, Ambios Technology, Inc.). The sheet resistance was measured by RTS-9 four-probe test system from Guangzhou 4Probes Tech. Inc., China. And the conductive type was determined using cold-hot probe method by a PN-12 conductive type measure system from Guangzhou 4Probes Tech. Inc., China.

\section{Results and Discussion}

The XRD patterns of films are shown in Figure 1(a). The as-deposited thin films, 5-LAY and 9-LAY, were poorly crystalline, while the annealed films, 5-LAY-ANN and 9-LAY-ANN, are well crystalline which match well the Kesterite structure of CZTS (JCPDS card 26-0575). The refined tetragonal lattices parameters for 9-LAY-ANN are $a=$ $b=5.42 \AA, c=10.83 \AA$, and $V=318.24 \AA^{3}$, analyzed by Jade5.0 software; however, for sample 5-LAY-ANN, the refined tetragonal lattices parameters were not figured out because of the major error. The crystallites size of 5LAY-ANN and 9-LAY-ANN was calculated as $24.9 \mathrm{~nm}$ and $31.8 \mathrm{~nm}$, respectively, using Debye-Scherrer formula by Jade5.0 software. 


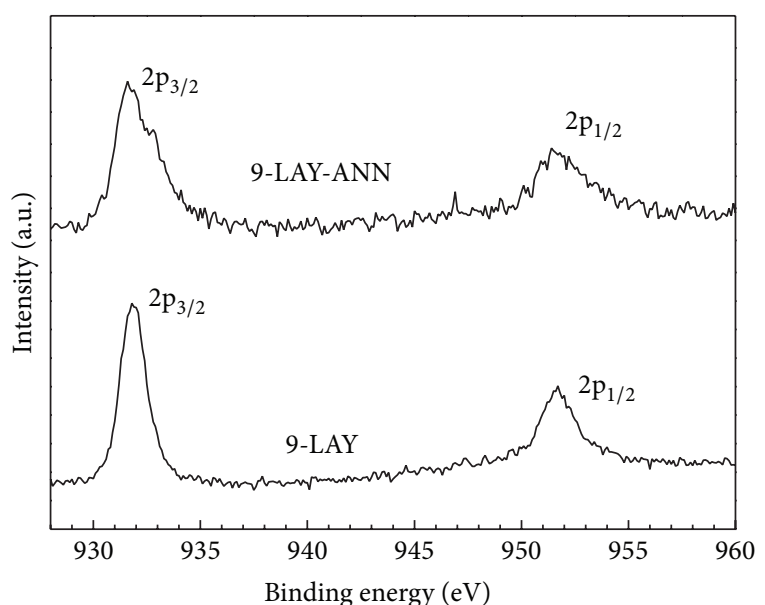

(a)

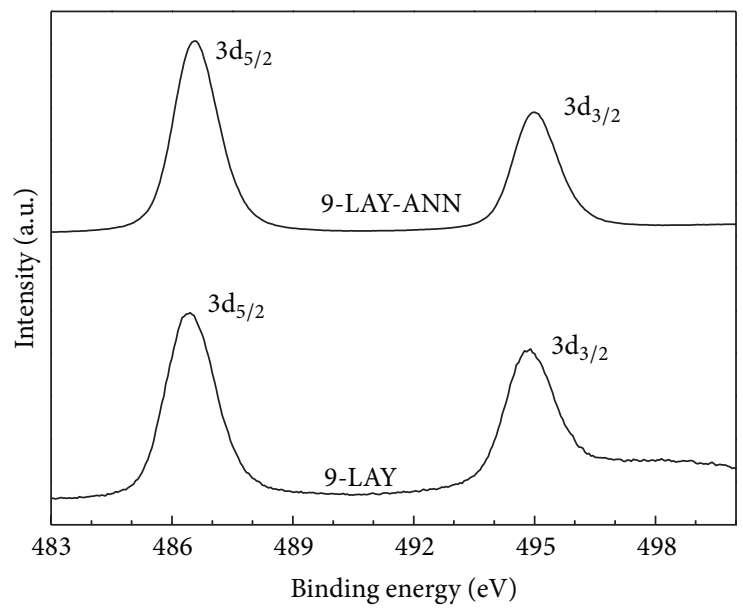

(c)

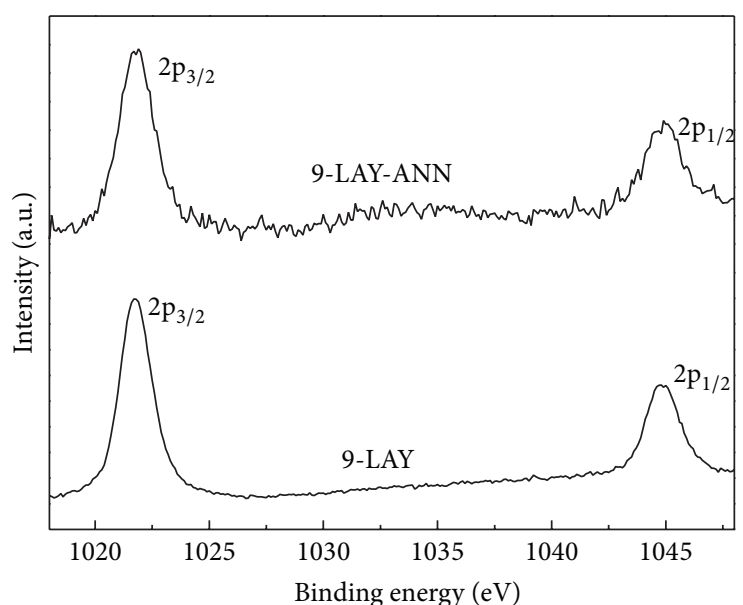

(b)

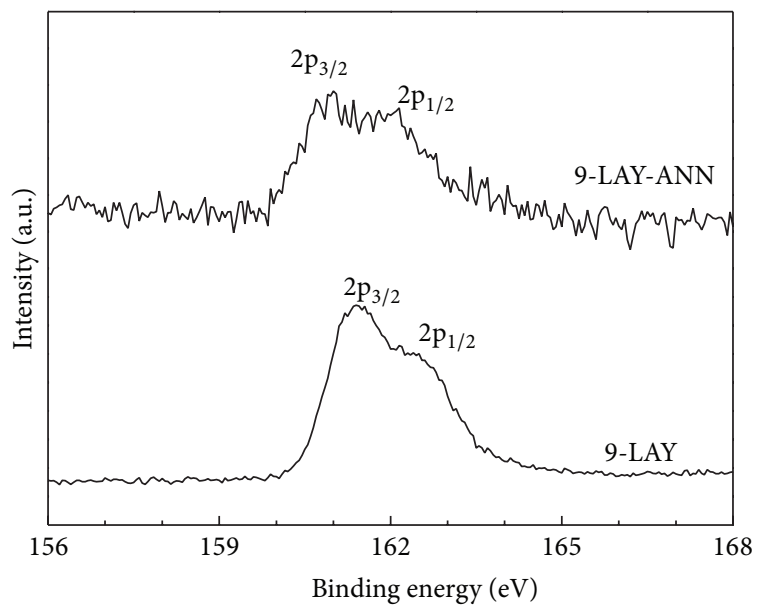

(d)

Figure 2: XPS spectra of 9-LAY and 9-LAY-ANN CZTS thin films: (a) Cu 2p, (b) Zn 2p, (c) Sn 3d, and (d) S 2p.

TABLE 2: Element binding energy values of CZTS films' XPS spectra.

\begin{tabular}{|c|c|c|c|c|c|c|c|c|}
\hline Sample & $\mathrm{Cu} 2 \mathrm{p}_{3 / 2}(\mathrm{eV})$ & $\mathrm{Cu} 2 \mathrm{p}_{1 / 2}(\mathrm{eV})$ & $\mathrm{Zn} 2 \mathrm{p}_{3 / 2}(\mathrm{eV})$ & $\mathrm{Zn} 2 \mathrm{p}_{1 / 2}(\mathrm{eV})$ & Sn $3 d_{5 / 2}(e V)$ & $\operatorname{Sn} 3 \mathrm{~d}_{3 / 2}(\mathrm{eV})$ & $\mathrm{S} 2 \mathrm{p}_{3 / 2}(\mathrm{eV})$ & $\mathrm{S} 2 \mathrm{p}_{1 / 2}(\mathrm{eV})$ \\
\hline 9-LAY & 932.0 & 951.4 & 1021.8 & 1044.7 & 486.5 & 494.9 & 161.5 & 163.0 \\
\hline 9-LAY-ANN & 931.7 & 951.7 & 1021.8 & 1044.9 & 486.6 & 495.0 & 161.0 & 162.5 \\
\hline
\end{tabular}

Since the (112), (200), (220), and (312) peaks of $\mathrm{Cu}_{2} \mathrm{ZnSnS}_{4}$ XRD pattern are very close to the (111), (200), (220), and (311) of ZnS XRD pattern (JCPDS card 65-5476), it is necessary to identify further the phases by Raman spectroscopy [16]. The Raman spectrum of 9-LAY-ANN is presented in Figure $1(\mathrm{~b})$. The $\mathrm{Cu}_{2} \mathrm{ZnSnS}_{4}$ Raman peaks are observed at $287 \mathrm{~cm}^{-1}$ and $338 \mathrm{~cm}^{-1}$, while the $\mathrm{ZnS}$ Raman peak is not observed at $351 \mathrm{~cm}^{-1}$, demonstrating a singlephase Kesterite CZTS.

XPS spectra of 9-LAY and 9-LAY-ANN CZTS thin films are shown in Figure 2. The element binding energy and the spin-orbit splitting values are listed in Tables 2 and 3, respectively, which are consistent with those reported in the literatures $[3,6,17]$. The almost same characteristics of XPS spectra between 9-LAY and 9-LAY-ANN demonstrate that
TABLE 3: Spin-orbit splitting values of CZTS films' XPS spectra.

\begin{tabular}{lcccc}
\hline Sample & $\mathrm{Cu} 2 \mathrm{p}(\mathrm{eV})$ & $\mathrm{Zn} 2 \mathrm{p}(\mathrm{eV})$ & $\mathrm{Sn} 3 \mathrm{~d}(\mathrm{eV})$ & $\mathrm{S} 2 \mathrm{p}(\mathrm{eV})$ \\
\hline 9-LAY & 19.4 & 22.9 & 8.4 & 1.5 \\
9-LAY-ANN & 20.0 & 23.1 & 8.4 & 1.5
\end{tabular}

the CZTS phase began to grow in the LBLSG process, which is consistent with XRD measurements, in which the broad and weak peaks of (112), (220), and (312) are observed for asdeposited samples.

The transmittance curves of the CZTS thin films are shown in Figure 3(a), and the Tauc curves calculated from the transmittance curves are shown in Figures 3(b)-3(e). The 


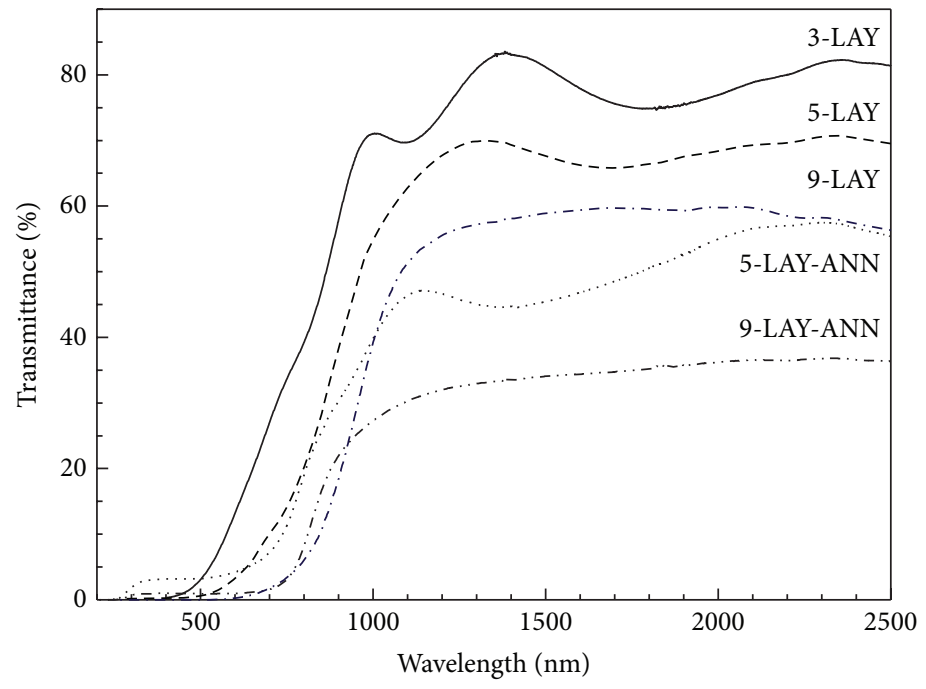

(a)

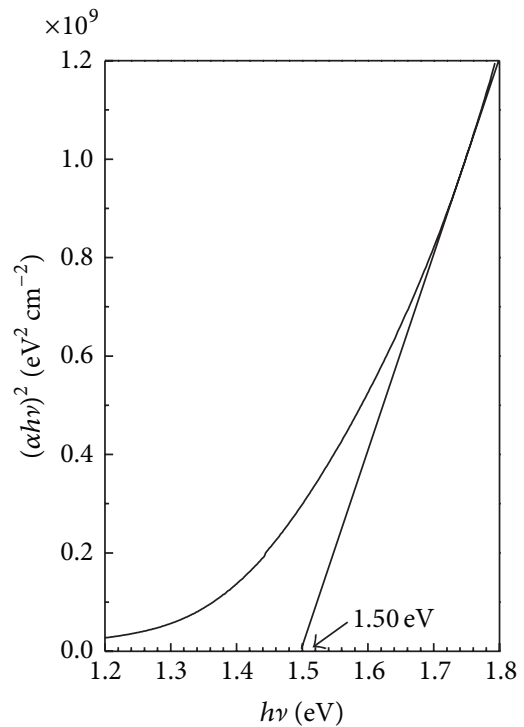

(c) 5-LAY

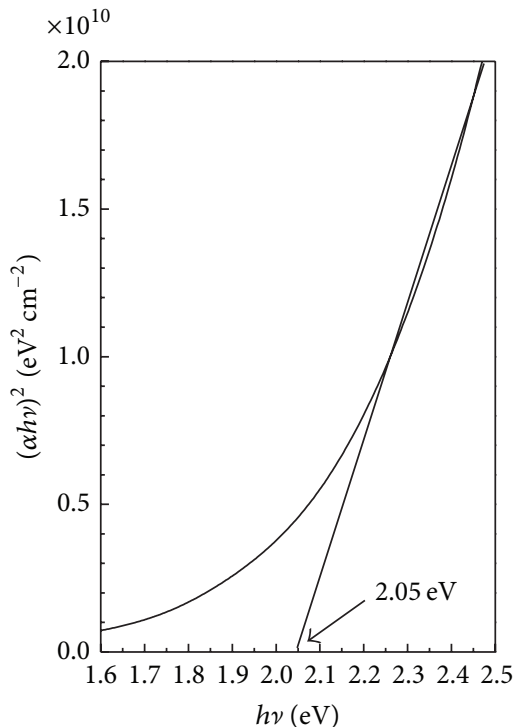

(b) 3-LAY
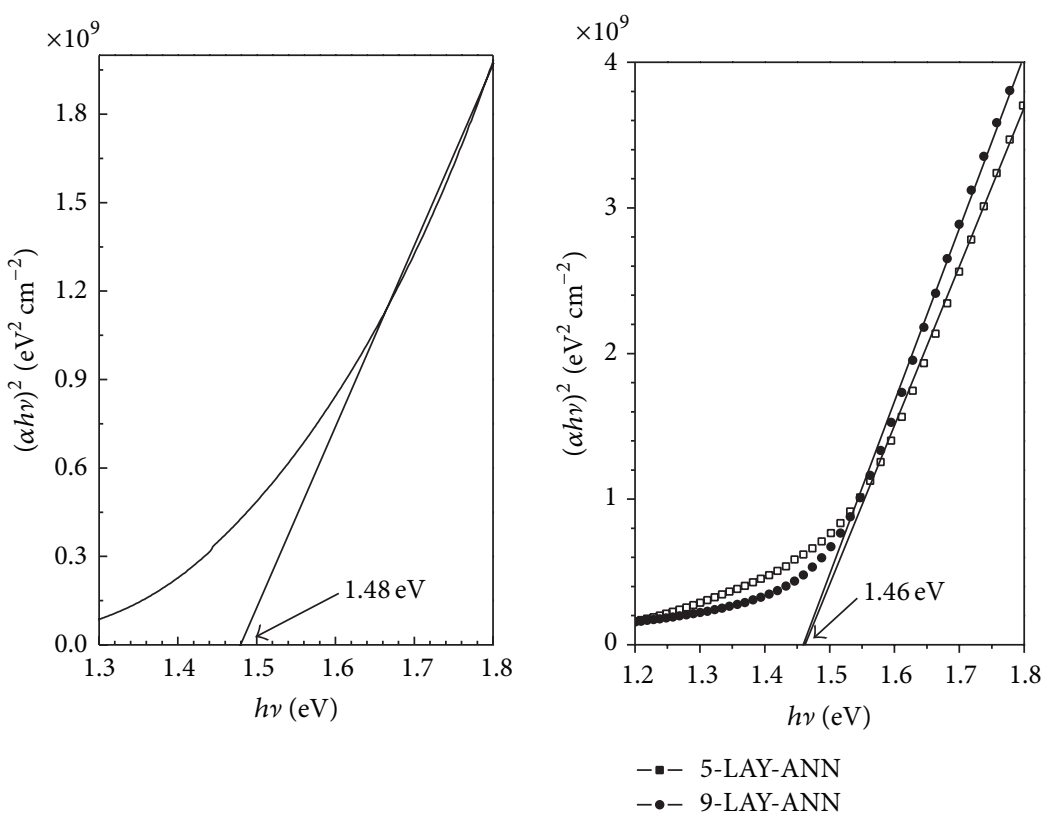

(e)

FIgUrE 3: (a) Transmittances of CZTS films. (b)-(e) Tauc curves of CZTS films.

absorption band-edge blue shift of sample 3-LAY transmittance is observed compared with 5-LAY. And the absorption band-edge blue shift of sample 5-LAY transmittance is observed compared with 9-LAY. The absorption band-edge is dependent on the material energy band structure, which is determined by the atom arrangement and crystallization degree. So 9-LAY film should have higher crystallinity than 5-LAY and 3-LAY. The optic energy gap from Tauc curves are listed in Table 4. The annealed samples of 5-LAY-ANN and 9-LAY-ANN have lower optic energy band gap compared with the as-deposited samples of 5-LAY and 9-LAY, which indicates that the annealed films present higher crystallinity. That is consistent with the XRD measurements.

Figure 4 shows SEM photographs concerning surface and cross section morphology of 9-LAY and 9-LAY-ANN CZTS films. There are no obvious grain characteristics for as-deposited 9-LAY film, while about $30 \mathrm{~nm}$ grains can be observed for the annealed 9-LAY-ANN film (see Figure 4). Besides, the as-deposited film is compact according to Figure 4(c), while the holes and bigger grains are observed for annealed film as shown in Figures 4(b) and 4(d). The region deposited by using the Lo-Con solution is more compact than 


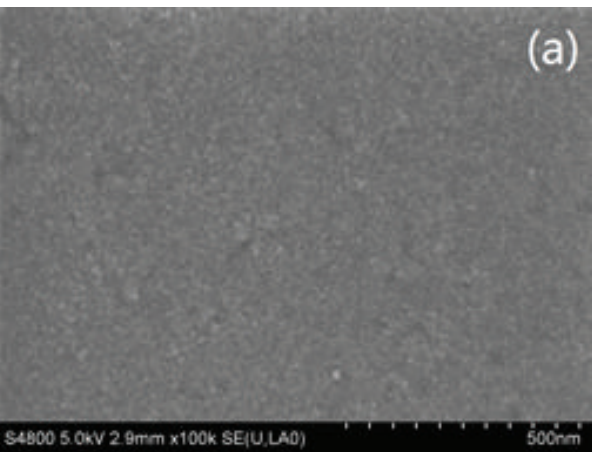

(a)

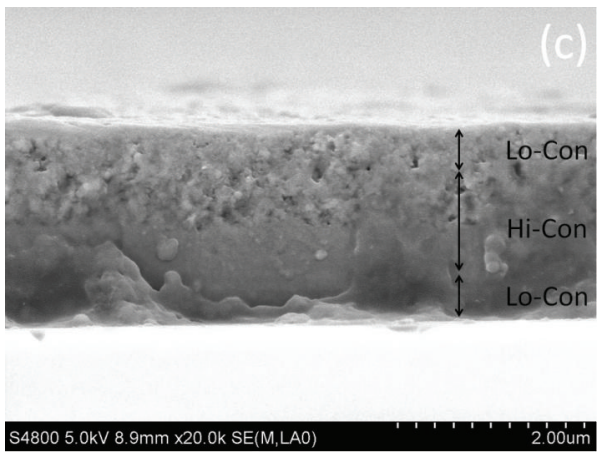

(c)

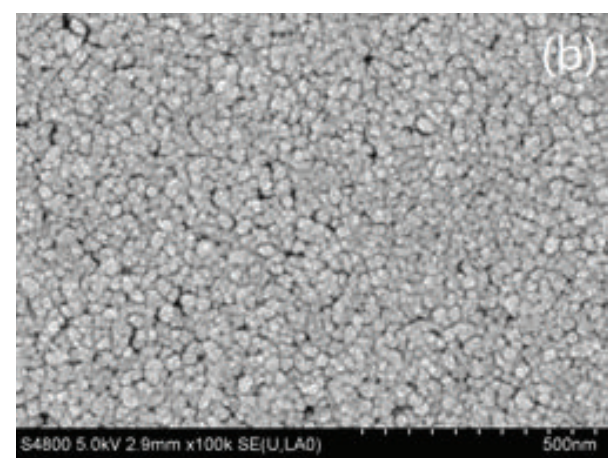

(b)

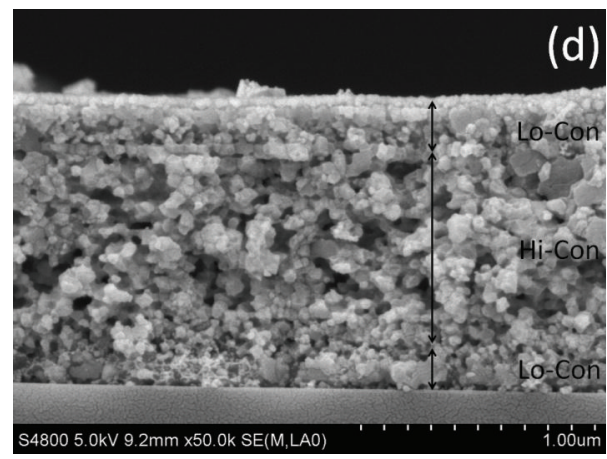

(d)

FIGURE 4: SEM photographs of CZTS films. (a) and (c) Surface and cross section of 9-LAY. (b) and (d) Surface and cross section of 9-LAYANN.

TABLE 4: Characterizations of the CZTS films.

\begin{tabular}{lcccc}
\hline Sample & Thickness $(\mu \mathrm{m})$ & Sheet resistance $(\Omega / \square)$ & Conduction type & Eg $(\mathrm{eV})$ \\
\hline 3-LAY & 0.4 & $\backslash$ & $\backslash$ & 1.05 \\
5-LAY & 1.3 & $5.25 \times 10^{3}$ & $\mathrm{P}$ & 1.50 \\
5-LAY-ANN & 0.9 & $\backslash$ & $\backslash$ & 1.46 \\
9-LAY & 1.7 & $4.08 \times 10^{3}$ & $\mathrm{P}$ & 1.48 \\
9-LAY-ANN & 1.2 & & 1.46 \\
\hline
\end{tabular}

TABLE 5: The compositions of the CZTS thin films.

\begin{tabular}{lccccccr}
\hline Sample & $\mathrm{Cu} \%$ & $\mathrm{Zn} \%$ & $\mathrm{Sn} \%$ & $\mathrm{~S} \%$ & $\mathrm{Cl} \%$ & $\mathrm{Cu} /(\mathrm{Zn}+\mathrm{Sn})$ & $\mathrm{Zn} / \mathrm{Sn}$ \\
\hline 9-LAY & 19.44 & 15.11 & 10.64 & 46.44 & 8.37 & 0.75 & 1.41 \\
9-LAY-ANN & 23.49 & 16.04 & 12.35 & 48.12 & $\backslash$ & 0.83 & 1.30 \\
\hline
\end{tabular}

that deposited by using the Hi-Con solution, as shown in Figures 4(c)-4(d).

Table 5 is the chemical compositions of CZTS films obtained by EDS measurement. There is $\mathrm{Cl}$ in the asdeposited sample, 9-LAY, but $\mathrm{Cl}$ is not detected from the annealed 9-LAY-ANN film. The ratio of $\mathrm{S} /(\mathrm{Cu}+\mathrm{Zn}+\mathrm{Sn})$ is 1.028 for 9-LAY and decreases to 0.928 after being annealed. The ratio of metal elements, $\mathrm{Cu} /(\mathrm{Zn}+\mathrm{Sn})$ and $\mathrm{Zn} / \mathrm{Sn}$, is 0.83 and 1.30, respectively, for the annealed 9-LAY-ANN, which is $\mathrm{Cu}$-poor and $\mathrm{Zn}$-rich.

The as-deposited films did not demonstrate obvious conduction type and their sheet resistances were too high to be measured by four-probe test system. The sheet resistances of
5-LAY-ANN and 9-LAY-ANN are $5.25 \mathrm{k} \Omega / \square$ and $4.08 \mathrm{k} \Omega / \square$, respectively, and their resistivity is $4.725 \times 10^{-1} \Omega \cdot \mathrm{cm}$ and $4.896 \times 10^{-1} \Omega \cdot \mathrm{cm}$, respectively. The film crystallinity change and $\mathrm{Cu}$-poor will promote the formation of copper vacancy in the annealing process, which is the reason that the conduction type and sheet resistance of the annealed films could be detected.

\section{Conclusion}

CZTS films were prepared by LBLSG technology without specific sulfurization. The CZTS phase began to form in 
the LBLSG process. And the grains grew up to $\sim 30 \mathrm{~nm}$ after being annealed. The optic energy gap is $1.50 \mathrm{eV}$ for asdeposited film and is $1.46 \mathrm{eV}$ after being annealed. The asdeposited and annealed films are both of Kesterite structure. The as-deposited films do not present obvious electric conduction type. However, the annealed film is p-type conduction and has sheet resistance of $4.08 \mathrm{k} \Omega / \square$ and resistivity of $4.896 \times 10^{-1} \Omega \cdot \mathrm{cm}$ for 9 -LAY-ANN film. The region deposited by using Lo-Con solution was more compact than that by the Hi-Con solution from SEM morphology images.

\section{Conflict of Interests}

The authors declare that there is no conflict of interests regarding the publication of this paper.

\section{Acknowledgments}

This work was supported by the National High Technology Research and Development Program (no. 2011AA050515) and Sichuan Province Science and Technology Support Program (no. 2013GZX0145).

\section{References}

[1] W. Shockley and H. J. Queisser, "Detailed balance limit of efficiency of p-n junction solar cells," Journal of Applied Physics, vol. 32, no. 3, pp. 510-519, 1961.

[2] B. Shin, O. Gunawan, Y. Zhu, N. A. Bojarczuk, S. J. Chey, and S. Guha, "Thin film solar cell with $8.4 \%$ power conversion efficiency using an earth-abundant Cu2ZnSnS4 absorber," Progress in Photovoltaics: Research and Applications, vol. 21, no. 1, pp. 7276, 2013.

[3] F. Jiang, H. Shen, and W. Wang, "Optical and electrical properties of $\mathrm{Cu}_{2} \mathrm{ZnSnS}_{4}$ film prepared by sulfurization method," Journal of Electronic Materials, vol. 41, no. 8, pp. 2204-2209, 2012.

[4] N. Muhunthan, O. P. Singh, S. Singh, and V. N. Singh, "Growth of CZTS thin films by cosputtering of metal targets and sulfurization in $\mathrm{H}_{2} \mathrm{~S}$," International Journal of Photoenergy, vol. 2013, Article ID 752012, 7 pages, 2013.

[5] X. Sheng, L. Wang, Y. Tian, Y. Luo, L. Chang, and D. Yang, "Lowcost fabrication of $\mathrm{Cu}_{2} \mathrm{ZnSnS}_{4}$ thin films for solar cell absorber layers," Journal of Materials Science: Materials in Electronics, vol. 24, no. 2, pp. 548-552, 2013.

[6] W. Wang, H. Shen, F. Jiang, X. He, and Z. Yue, "Low-cost chemical fabrication of $\mathrm{Cu}_{2} \mathrm{ZnSnS}_{4}$ microparticles and film," Journal of Materials Science: Materials in Electronics, vol. 24, no. 6, pp. 1813-1817, 2013.

[7] N. M. Shinde, C. D. Lokhande, J. H. Kim, and J. H. Moon, "Low cost and large area novel chemical synthesis of $\mathrm{Cu} 2 \mathrm{ZnSnS} 4$ (CZTS) thin films," Journal of Photochemistry and Photobiology A: Chemistry, vol. 235, pp. 14-20, 2012.

[8] M. Jeon, T. Shimizu, and S. Shingubara, "Cu2ZnSnS4 thin films and nanowires prepared by different single-step electrodeposition method in quaternary electrolyte," Materials Letters, vol. 65, no. 15-16, pp. 2364-2367, 2011.

[9] K. Maeda, K. Tanaka, Y. Nakano, and H. Uchiki, "Annealing temperature dependence of properties of $\mathrm{Cu}_{2} \mathrm{ZnSnS}_{4}$ thin films prepared by sol-gel sulfurization method," Japanese Journal of Applied Physics, vol. 50, no. 5, Article ID 05FB08, 2011.

[10] K. Tanaka, Y. Fukui, N. Moritake, and H. Uchiki, "Chemical composition dependence of morphological and optical properties of $\mathrm{Cu}_{2} \mathrm{ZnSnS}_{4}$ thin films deposited by sol-gel sulfurization and $\mathrm{Cu}_{2} \mathrm{ZnSnS}_{4}$ thin film solar cell efficiency," Solar Energy Materials and Solar Cells, vol. 95, no. 3, pp. 838-842, 2011.

[11] P. K. Sarswat and M. L. Free, "Demonstration of a sol-gel synthesized bifacial CZTS photoelectrochemical cell," Physica Status Solidi A, vol. 208, no. 12, pp. 2861-2864, 2011.

[12] K. Maeda, K. Tanaka, Y. Fukui, and H. Uchiki, "Influence of $\mathrm{H}_{2} \mathrm{~S}$ concentration on the properties of $\mathrm{Cu}_{2} \mathrm{ZnSnS}_{4}$ thin films and solar cells prepared by sol-gel sulfurization," Solar Energy Materials and Solar Cells, vol. 95, no. 10, pp. 2855-2860, 2011.

[13] K. Tanaka, N. Moritake, and H. Uchiki, "Preparation of $\mathrm{Cu}_{2} \mathrm{ZnSnS}_{4}$ thin films by sulfurizing sol-gel deposited precursors," Solar Energy Materials \& Solar Cells, vol. 91, no. 13, pp. 1199-1201, 2007.

[14] M. Y. Yeh, C. C. Lee, and D. S. Wuu, "Influences of synthesizing temperatures on the properties of $\mathrm{Cu}_{2} \mathrm{ZnSnS}_{4}$ prepared by sol-gel spin-coated deposition," Journal of Sol-Gel Science and Technology, vol. 52, no. 1, pp. 65-68, 2009.

[15] H. Park, Y. H. Hwang, and B. Bae, "Sol-gel processed $\mathrm{Cu}_{2} \mathrm{ZnSnS}_{4}$ thin films for a photovoltaic absorber layer without sulfurization," Journal of Sol-Gel Science and Technology, vol. 65, no. 1, pp. 23-27, 2013.

[16] A. Nagaoka, K. Yoshino, H. Taniguchi, T. Taniyama, and H. Miyake, "Preparation of $\mathrm{Cu}_{2} \mathrm{ZnSnS}_{4}$ single crystals from $\mathrm{Sn}$ solutions," Journal of Crystal Growth, vol. 341, no. 1, pp. 38-41, 2012.

[17] W. Liu, B. Guo, C. Mak, A. Li, X. Wu, and F. Zhang, "Facile synthesis of ultrafine $\mathrm{Cu}_{2} \mathrm{ZnSnS}_{4}$ nanocrystals by hydrothermal method for use in solar cells," Thin Solid Films, vol. 535, no. 1, pp. 39-43, 2013. 

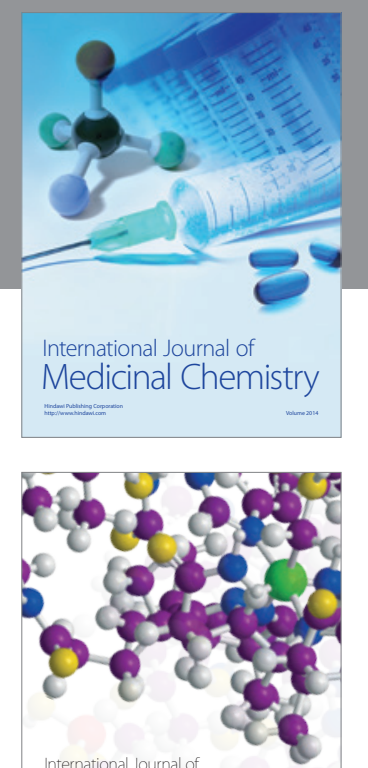

\section{Carbohydrate} Chemistry

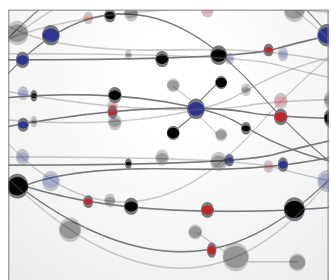

The Scientific World Journal
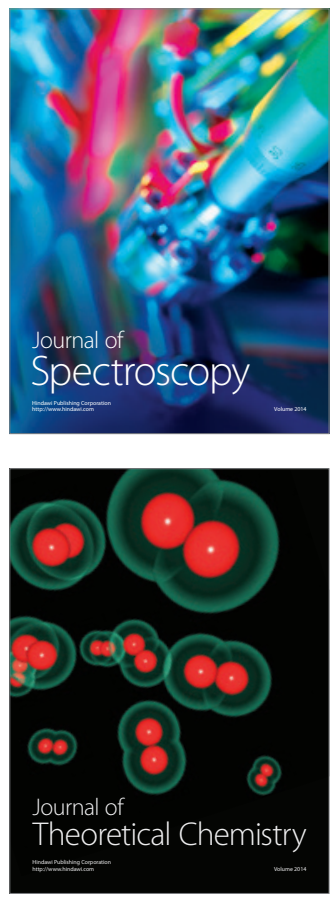
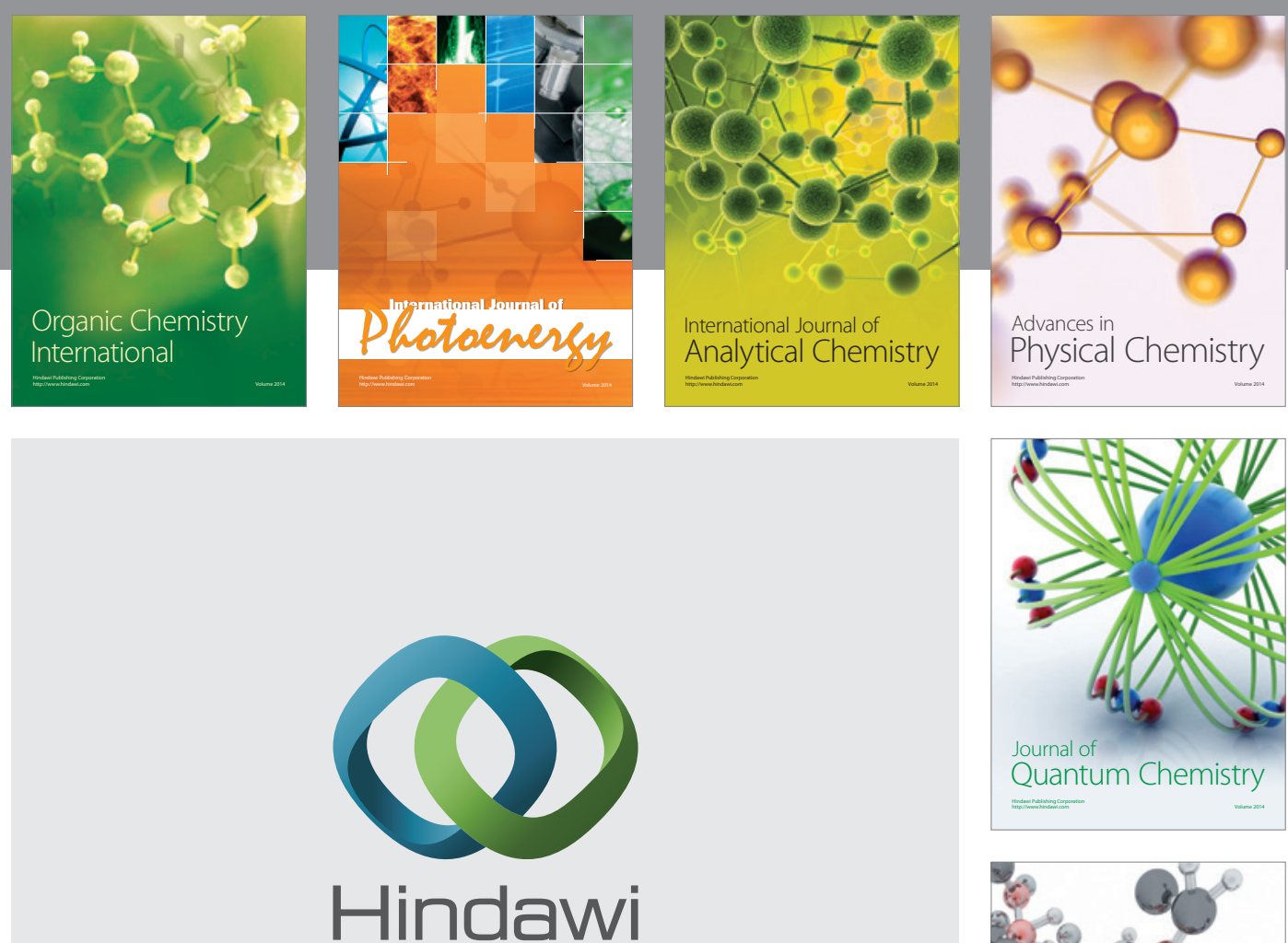

Submit your manuscripts at

http://www.hindawi.com

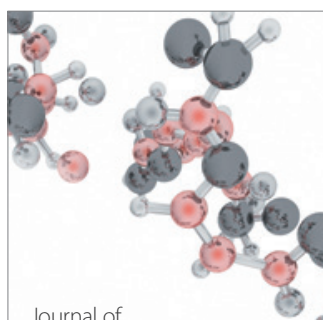

Analytical Methods

in Chemistry

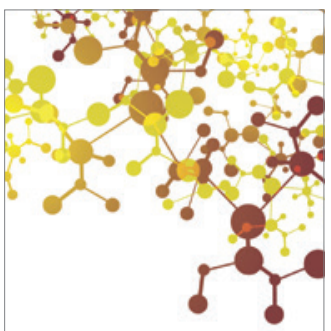

Journal of

Applied Chemistry

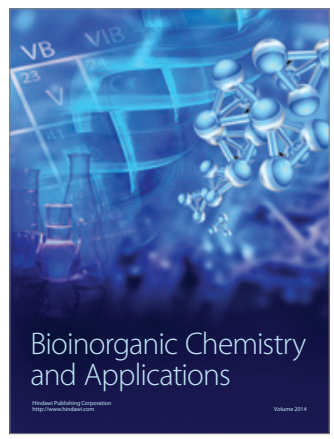

Inorganic Chemistry
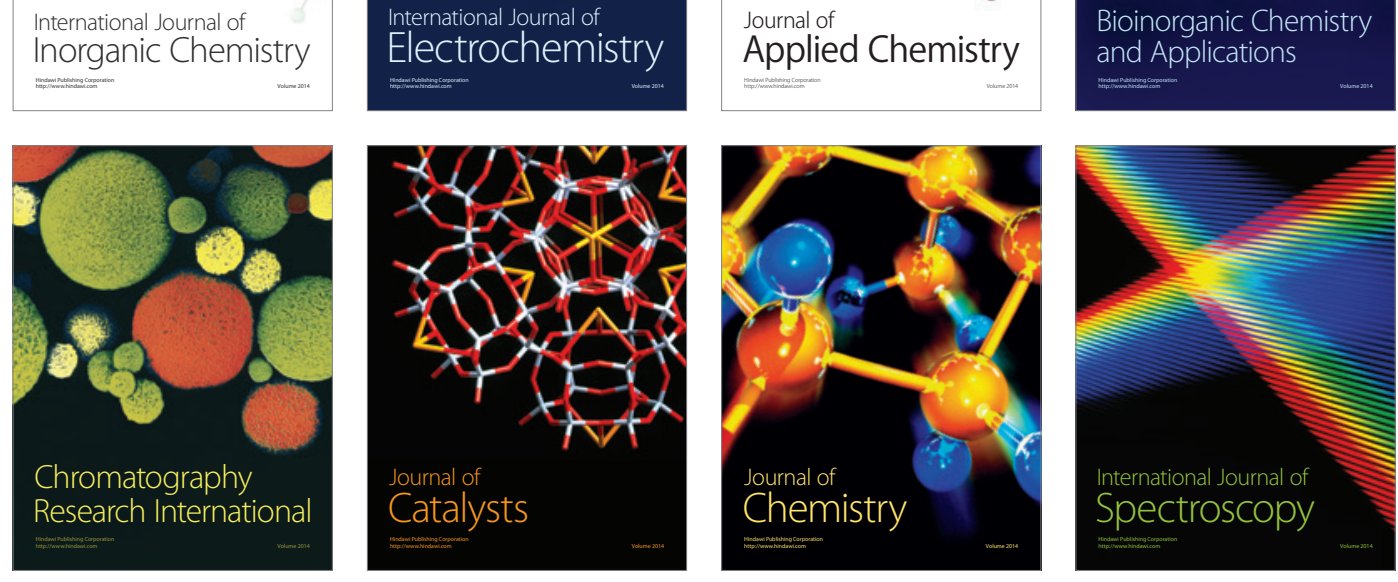